\title{
CEPH/Genethon Map
}

National Cancer Institute

\section{Source}

National Cancer Institute. CEPH/Genethon Map. NCI Thesaurus. Code C16055.

An integ rated physical and genetic linkage map of the human genome produced by the Centre d'Etude du Polymorphisme Humain (CEPH) and the Genethon research laboratories. 